\title{
DEMOKRASI DI ERA PANDEMI
}

\author{
Ramadhan Yusuf Firdhaus \\ IIK STRADA INDONESIA \\ yframa@gmail.com
}

\begin{abstract}
Abstrak
Demokrasi adalah sistem pemerintahan di mana hukum, kebijakan, kepemimpinan, dan usaha besar dari suatu negara atau pemerintahan lain secara langsung atau tidak langsung diputuskan oleh rakyat. Virus Corona atau severe acute respiratory syndrome coronavirus 2 (SARS-CoV2) adalah virus yang menyerang sistem pernapasan. Penyakit karena infeksi virus ini disebut Covid19. Virus Corona bisa menyebabkan gangguan ringan pada sistem pernapasan, infeksi paru-paru yang berat, hingga kematian. Demokrasi yang terbatas selama pandemi, memicu asumsi banyak orang pemerintah berupaya memusatkan kekuasaan. Covid-19 membuat kebiasaan baru dan meningkatkan kesadaran pada banyak hal. Namun karakteristik pemerintah dan kemampuan memerintah lah yang memberikan lebih banyak imbas dalam mempertahankan keberadaan demokrasi dan politik secara luas, dibandingkan keberadaan pandemi sendiri.
\end{abstract}

\section{Kata Kunci : Demokrasi, Pandemi, Covid-19}

\begin{abstract}
Democracy is a system of government in which the laws, policies, leadership, and great efforts of a country or other government are directly or indirectly decided by the people. Coronavirus or severe acute respiratory syndrome coronavirus 2 (SARS-CoV-2) is a virus that attacks the respiratory system. The disease due to this viral infection is called Covid-19. Corona virus can cause mild disruption of the respiratory system, severe lung infections, to death. Democracy was limited during the pandemic, fueling the assumption that many governments were trying to concentrate power. Covid-19 makes new habits and raises awareness in many ways. But it is the characteristics of government and the ability to govern that have more impact on maintaining a widespread democratic and political existence than the existence of the pandemic itself.
\end{abstract}

\section{Keywords: Democracy, Pandemic, Covid-19}

\section{A. Latar Belakang}

Demokrasi adalah sistem pemerintahan di mana hukum, kebijakan, kepemimpinan, dan usaha besar dari suatu negara atau pemerintahan lain secara langsung atau tidak langsung diputuskan oleh rakyat. 
Secara etimologis, kata demokrasi berasal dari bahasa Yunani yaitu 'Demos' dan 'Kratos'. Demos artinya rakyat/ khalayak, dan Kratos artiya pemerintahan.

Menurut Kamus Besar Bahasa Indonesia (KBBI), demokrasi adalah bentuk atau sistem pemerintahan yang seluruh rakyatnya turut serta memerintah dengan perantaraan wakilnya yang terpilih. Jadi, pengertian demokrasi adalah pemerintahan yang diselenggarakan dari rakyat, untuk rakyat, dan oleh rakyat.

Dalam demokrasi, setiap warga negara diperbolehkan untuk berpartisipasi, baik secara langsung atau melalui perwakilan dalam perumusan, pengembangan, dan pembuatan hukum.

Setiap negara menganut sistem pemerintahan yang berbeda. Di beberapa negara, istilah demokrasi banyak digunakan sebuah negara untuk menggambarkan sistem pemerintahan yang dianut.

Virus Corona atau severe acute respiratory syndrome coronavirus 2 (SARS-CoV-2) adalah virus yang menyerang sistem pernapasan. Penyakit karena infeksi virus ini disebut Covid19. Virus Corona bisa menyebabkan gangguan ringan pada sistem pernapasan, infeksi paru-paru yang berat, hingga kematian.

Severe acute respiratory syndrome coronavirus 2 (SARS-CoV-2) yang lebih dikenal dengan nama virus Corona adalah jenis baru dari coronavirus yang menular ke manusia. Virus ini bisa menyerang siapa saja, seperti lansia (golongan usia lanjut), orang dewasa, anak-anak, dan bayi, termasuk ibu hamil dan ibu menyusui.

Infeksi virus Corona disebut COVID-19 (Corona Virus Disease 2019) dan pertama kali ditemukan di kota Wuhan, China pada akhir Desember 2019. Virus ini menular dengan sangat cepat dan telah menyebar ke hampir semua negara, termasuk Indonesia, hanya dalam waktu beberapa bulan.

Hal tersebut membuat beberapa negara menerapkan kebijakan untuk memberlakukan lockdown dalam rangka mencegah penyebaran virus Corona. Di Indonesia sendiri, pemerintah menerapkan kebijakan Pemberlakukan Pembatasan Kegiatan Masyarakat (PPKM), melakukan penerapan social distancing, mengeluarkan himbauan untuk Work From Home bagi pegawai, membangun RS khusus untuk penanganan Covid-19, dan lain-lain. Dengan adanya kebijakan pemerintah ini serta situasi yang semakin genting, tentunya memberikan dampak bagi masyarakat, baik masyarakat menengah ke bawah hingga kalangan elit.

Covid-19 mengubah kebiasaan dan perilaku masyarakat. Tak khayal juga dalam segi politik, pandemi menciptakan regulasi-regulasi baru dan cara pikir pemerintah serta masyarakat di 
level lokal maupun global. Covid-19 juga mengubah demokrasi parlemen, partai politik, elektoral dalam melaksanakan fungsi mereka. Sebagai negara demokrasi, Indonesia perlu berhati-hati dalam mengambil kebijakan terkait pandemi tanpa mengurangi nilai demokrasi.

Hingga saat ini, demokrasi dianggap sebagai sistem politik yang maju, namun tak bisa dipungkiri bahwa demokrasi masih memiliki banyak celah tantangan yang besar. Peneliti Pusat Penelitian Politik LIPI, Firman Noor, dalam penelitiannya yang berjudul "Pandemic Covid-19 and The Challenge for Democracy: Indonesia Case" menunjukkan bahwa data dari Economy Intellegent Unit menunjukan adanya stagnansi qualitas demokrasi dalam 10 tahun terakhir, dari 5.55 pada 2018 menjadi 5.44 pada 2020. Pembatasan yang dibuat pemerintah untuk masyarakat atas nama keamanan, memicu asumsi banyak orang bahwa pemerintah berupaya memusatkan kekuasaan, termasuk dalam pengambilan keputusan, yang dapat digunakan untuk kepentingan politik.

\section{B. Kasus / Masalah}

Demokrasi yang terbatas selama pandemi, memicu asumsi banyak orang pemerintah berupaya memusatkan kekuasaan.

\section{Tinjauan Pustaka}

Indonesia menjadi satu di antara negara yang menganut sistem pemerintahan secara demokrasi. Negara yang menganut sistem demokrasi akan memberikan kebebasan warga negaranya untuk menyampaikan pendapat. Untuk lebih memahami lebih dalam tentang demokrasi, bisa membaca pengertian dari para ahli, hingga jenis-jenisnya.

Berikut ini rangkuman tentang pengertian demokrasi menurut para ahli hingga jenisjenisnya, seperti dikutip dari laman Saintif dan GuruPPKN

\section{Abraham Lincoln}

Menurut Abraham Lincoln, demokrasi adalah pemerintahan dari rakyat, oleh rakyat, dan untuk rakyat (government of the people, by the people, and for the people).

\section{Charles Costello}

Demokrasi adalah sistem sosial dan politik pemerintahan diri dengan kekuasaan-kekuasaan pemerintah yang dibatasi hukum dan kebiasaan untuk melindungi hak-hak perorangan warga negara. 


\section{John L. Esposito}

Demokrasi adalah kekuasaan dari dan untuk rakyat. Jadi, setiap warga negara berhak untuk berpartisipasi, baik terlibat aktif maupun mengontrol kebijakan yang dikeluarkan oleh pemerintah.

4. Hans Kelsen

Demokrasi adalah pemerintahan oleh rakyat dan untuk rakyat. Kemudian yang melaksanakan kekuasaan negara ialah wakil-wakil rakyat yang terpilih.

\section{Sidney Hook}

Demokrasi adalah bentuk pemerintahan di mana keputusan-keputusan pemerintah yang penting secara langsung atau tidak, didasarkan pada kesepakatan mayoritas yang diberikan secara bebas dari rakyat dewasa.

\section{C.F. Strong}

Demokrasi adalah suatu sistem pemerintahan di mana mayoritas anggota dewan dari masyarakat ikut serta dalam politik atas dasar sistem perwakilan.

\section{Hannry B. Mayo}

Demokrasi adalah kebijaksanaan umum, ditentukan atas dasar mayoritas oleh wakil-wakil yang diawasi secara efektif oleh rakyat dalam pemilihan-pemilihan yang didasarkan atas prinsip kesamaan politik serta diselenggarakan dalam suasana kebebasan politik.

8. H. Harris Soche

Demokrasi adalah suatu bentuk pemerintahan rakyat. Dengan kata lain, rakyat merupakan pemegang kekuasaan dalam pemerintahan yang memiliki hak untuk mengatur, mempertahankan, serta melindungi diri mereka dari adanya paksaan dari wakil-wakil mereka.

9. Abdul Ghani Ar Rahhal

Demokrasi yaitu suatu bentuk kekuasaan rakyat oleh rakyat, artinya rakyat merupakan sumber kekuasaan.

10. Philippe C. Schmitter 
Demokrasi merupakan suatu teori yang menyatakan bahwa suatu negara supaya tanggap terhadap kebutuhan maupun kepentingan warganya.

Secara umum, sistem demokrasi dibagi menjadi dua jenis, yaitu sistem demokrasi langsung dan sistem demokrasi perwakilan.

1. Demokrasi langsung

Dalam sistem demokrasi langsung, setiap rakyat berhak memberikan aspirasinya melalui pendapat atau suara dalam menentukan sebuah keputusan. Biasanya, setiap rakyat mewakili dirinya sendiri dalam memilih kebijakan sehingga secara langsung keadaan politik berada di tangan rakyat.

Namun, sistem demokrasi langsung jarang diterapkan di era modern. Hal ini dikarenakan kepadatan penduduk serta kurangnya minat penduduk untuk mempelajari keseluruhan permasalahan politik di negara tersebut.

2. Demokrasi perwakilan

Dalam sistem demokrasi perwakilan, seluruh rakyat memberikan pendapatnya melalui pemilihan umum dalam memilih wakil rakyat. Setelah terpilih, wakil rakyat tersebut mengutarakan aspirasi rakyatnya dalam mengatasi permasalahan negara.

Melambatnya ekonomi merupakan satu dari berbagai imbas penyebaran Covid-19 yang menjadi fokus perhatian. Namun, ada imbas lain yang penting untuk diperhatikan, di antaranya adalah tantangan demokrasi dan keamanan suatu negara.

Pada beberapa negara, pandemi telah memperkuat kuasa otoritas pada masyarakat. Mereka lebih ketat dan menggunakan pendekatan autrokasi dengan menggunakan kebijakan top-down absolut. Namun beberapa negara juga sukses mengimplementasikan nilai demokrasi dalam penanganan pandemi. Seperti Jerman, Norwegia, Finlandia, Taiwan, dan Korea Selatan. Negara-negara tersebut memperhatikan kebutuhan masyarakat dan berdiskusi dengan ilmuwan serta komunitas dalam proses pengambilan keputusan. Pemerintah dan masyarakat berusaha mencari solusi yang dapat dilakukan bersama.

\section{Pembahasan}

Kondisi demokrasi di Indonesia saat ini sedang dalam masa kepungan ketidakpastian ekonomi bahkan sebelum coronavirus, dan semakin parah setelah terdampak Covid-19. Covid19 juga berpotensi menjadi faktor penghambat penerapan prinsip-prinsip demokrasi dalam 
kehidupan bermasyarakat, berbangsa , dan bernegara. Indonesia sebagai salah satu negara yang memiliki dampak dari pandemi COVID-19 ini mengalami banyak kerugian seperti dalam hal social, ekonomi dan budaya bahkan dengan adanya virus ini tidak sedikit orang-orang dari berbagai negara yang telah meninggal karena daya tahan tubuh mereka yang tidak kuat melawan virus tersebut.

Kekhawatiran semacam ini tidak hanya berkembang di Indonesia saja tapi juga negaranegara di belahan dunia lainnya. Pandemi Covid-19 yang menerpa hampir seluruh negara di dunia menghadirkan limitasi-limitasi tersendiri yang menuntut perubahan cara pandang dan mekanisme kerja yang tidak biasanya. Dalam konteks politik, pandemic Covid-19 telah merubah signifikan proses formulasi kebijakan yang dilakukan oleh pemerintah, cara kerja parlemen dalam menjalankan tugas pokok dan fungsinya, pelaksanaan politik electoral, strategi partai dalam mencapai kepentingan politiknya dan masih banyak lagi.

\section{E. Kesimpulan}

Covid-19 membuat kebiasaan baru dan meningkatkan kesadaran pada banyak hal. Namun karakteristik pemerintah dan kemampuan memerintah lah yang memberikan lebih banyak imbas dalam mempertahankan keberadaan demokrasi dan politik secara luas, dibandingkan keberadaan pandemi sendiri.

Perubahan-perubahan tersebut secara umum meruapakan proses natural sebagai bentuk fleksibilitas dan adaptasi terhadap situasi darurat atau kegentingan yang terjadi. Sebagai contoh, penerapan PPKM darurat yang dikritik masyarakat karena membatasai mereka dalam bermatapencaharian terkesan tidak demokratis karena tidak sepenuhnya dikehendaki oleh masyarakat. Akan tetapi formulasi kebijakan yang dilakukan oleh pemerintah pada dasarnya berbasis kepentingan rakyat, yakni agar mereka tidak terpapar Covid-19 yang semakin mengganas penyebarannya.

Pada kasus kebijakan PPKM Darurat tersebut terlihat jelas bahwa formulasi kebijakan yang dijalankan pemerintah terkesan tidak berbasis aspirasi rakyat. Namun demikian, pilihan kebijakna yang dilakukan oleh pemerintah merujuk pada sirkumtansi yang ada, yang mana kasus positif semakin meluas dan dibutuhkan pembatasan aktivitas masyarakat untuk mengendalikannya. Jika aktivitas masyarakat tidak dibatasi, maka memberikan signifikansi negative terhadap masyarakat itu sendiri. Demokrasi sejatinya merupakan system politik yang paling mapan dan hamper dijalankan oleh seluruh negara di dunia. Indonesia sendiri menganut demokrasi yang berbasis Pancasila. Meskipun frasa demokrasi secara eksplisit tidak tercantum pada Pancasila dan konstitusi, namun secara implisit nilai-nilai demokrasi seperti musyawarah 
mufakat dan penghargaan terhadap hak asasi manusia tercantum dalam dua kondensus dasar kebangsaan tersebut. Pemerintah Indonesia juga berkomitmen untuk mengembangkan demokrasi dengan melakukan penguatan pada hak-hak politik. Tidak dipungkiri, meskipun system politik yang mapan dan memiliki keselarasan dengan ideologi dan konstitusi, masih terdapat celah besar dan tantangan dalam penerapan demokrasi di Indonesia. 


\section{Daftar Pustaka}

- Cristy, Meri Dame.2021. Virus Corona

https://www.alodokter.com/virus-corona

- Firhaus, Ramadhan.2021. Peran Serta Masyarakat Dalam Upaya Penanggulangan Pandemi Covid-19

- Sodik,M.A. \& Fidhiniyah Nur. R.2021. Krisis Ekonomi Di Indonesia Di Sebabkan Oleh Pandemi Covid 19

- $\quad$ News, Tribun.2021. Konsolidasi Demorasi di Era Pandemi

https://www.tribunnews.com/tribunners/2021/08/31/konsolidasi-demokrasi-di-era-pandemi

- Tri, Nugroho Fauzan.2020. Pengertian Demokrasi Sejarah Singkat dan Jenis-Jenisnya

https://www.bola.com/ragam/read/4400454/pengertian-demokrasi-sejarah-singkat-dan-jenis-jenisnya

- $\quad$ Admin, Super.2021. Demokrasi di Era Pandemi Covid-19

https://ip.umy.ac.id/kritik-demokrasi-di-era-pandemi-covid-19/ 